\title{
IKHWANUL MUSLIMIN DAN DEMOKRASI DI MESIR
}

\author{
Said Abdullah Syahab \\ UIN Raden Fatah Palembang \\ syahababdullah@gmail.com
}

\begin{abstract}
Democratization in Muslim-majority countries has been running since the end of World War II, not just secularists who participated in the elections but Islamic movements like the Muslim Brotherhood stamped as radical and identical with terrorism also took part in the democratic party in Egypt. Despite having to deal with authoritarian leaders and experienced various kinds of terror, torture and murder, this Islamic movement still istiqomah even in the end get the trust of Egyptian society.

Demokirasi di negara-negara mayoritas muslim bergulir sejak berakhirnya perang dunia II, bukan hanya kalangan sekuler yang mengikuti Pemilu namun gerakan Islam seperti Ikhwanul Muslimin yang dicap radikal dan identik dengan terorisme juga mengambil bagian dalam pesta demokrasi di Mesir, Walau harus berhadapan dengan pemimpin otoriter dan mengalami berbagai macam teror, penyiksaan dan pembunuhan, gerakan Islam ini tetap istiqomah bahkan pada akhirnya mendapatkan kepercayaan masyarakat Mesir.
\end{abstract}

Keywords: Ikhwanul Muslimin, al-Banna, Mesir, Demokrasi

\section{Pendahuluan}

Demokrasi adalah sistem politik yang menjamin kedaulatan rakyat, konsep ini telah digunakan di berbagai negara dunia setelah berakhirnya Perang Dunia $\mathrm{II}^{1}$, khususnya negara berpenduduk

1 Perubahan yang mendorong demokratisasi pemerintahanpada negaranegara di berbagai belahan dunia telah mulai melaksanakan reformasi politik dan demokrasi yang cenderung pada desentralisasi dan pemberdayaan pemerintahan

TAJDID vol. XVI, No. 2, Juni - Desember 2017 | 191 


\section{Said Abdullah Syahab}

mayoritas muslim. ${ }^{2}$ Dimana negara-negara menjalankan pemilihan umum secara periodik untuk melakukan pergantian kepemimpinan negara dan memungkinkan terwujudnya artikulasi kehendak politik rakyat. ${ }^{3}$ Yusuf Qardhawi berpandangan bawah subtansi demokrasi sejalan dengan Islam, proses pemilihan melibatkan banyak orang untuk mengangkat seorang yang berhak menjadi pemimpin daerah atau negara berdasarkan suara mayoritas dan sebagai upaya usaha untuk menghindarkan dari penguasa yang tirani tidak bertentangan dengan prinsip Islam. Gagasan demokrasi telah diterima oleh masyarakat di negara-negara berpenduduk mayoritas berpenduduk muslim namun para pemikir Islam yang mempelajari budaya Barat menekankan pentingnya umat Islam untuk mengadopsi hukumhukum Barat dengan cara selektif. ${ }^{4}$

Sebagian pemikir Islam beryakinan bahwa berpandangan hubungan antara Islam dan demokrasi adalah dua hal yang berbeda dan Islam bertentangan dengan demokrasi. Maka di kalangan masyarakat muslim yang teguh dalam menjalankan agama akan menolak konsep demokrasi. Sebagian pemikir Islan membantah pandangan tersebut seperti Syaiful Mujani yang telah melakukan penelitian. Dalam penelitiannhya Syaiful Mujani. menunjukkan bahwa sesungguhnya umat Muslim dapat menerima nilai-nilai atau budaya demokrasi. Keterlibatan umat Muslim untuk selanjutnya akan berkontribusi besar terhadap keterlibatan politik, partisipasi politik dan dukungan terhadap demokrasi. Partisipasi umat Muslim dalam berbagai kelompok keagamaan, baik pada tingkat lokal dan

lokal. Brian Clive Smith, Understanding Third World Politics: Theories of Political Change and Development (Indiana USA: Indiana University Press, 2003), 23

2 Demokrasi dicetuskan Abraham Lincoln, yaitu terbentuknya pemerintahan dari rakyat, oleh rakyat dan untuk rakyat; government of the people, by the people, and for the people.Gabor S. Borritt dan Bradley R. Hoch, The Lincoln Trail in Pennsylvania (Pennsylvania: Pennsylvania State University Press, 2001), 51. S Miriam Budiardjo, Dasar-dasar Ilmu Politik (Jakarta: Gramedia, 1986) 46-49. Ramlan Surbakti, Memahami Imu Politik (Jakarta: Grasindo, 1993), 281.

3 Samuel P. Huntington, The Third Wave: Democratization in The Late Twentieth Century (London and Norman: University of Oklahoma Press, 1991), 127.

${ }^{4}$ John L. Esposito dan John Obert Vol.1, Islam and Democracy, (New York: Oxford University Press, 1996), 49.

192 | TAJDID Vol. XVI, No. 2, Juni - Desember 2017 
nasional merupakan hal penting bagi partisipasi politik kewarganeraan yang plural dan menjadi penghubung warga dengan sistem demokrasi. Kemudian sebagian pemikir Islam lainnya mengambil sikap pertengahan dalam mensikapi perbedaan terhadap konsep demokrasi dengan bersifat kritis dalam menerima nilai-nilai demokrasi dari Barat. ${ }^{5}$

\section{Sekuler dan Demokrasi dalam Perspektif Islam}

Secular berasal dari bahasa Latin saeculum, mengandung suatu makna yang ditandai dengan dua pengertian yaitu waktu dan tempat atau ruang. Sekular dalam pengertian waktu merujuk kepada 'sekarang' atau 'kini', sedangkan dalam pengertian ruang merujuk kepada 'dunia' atau 'duniawi'. 'Sekularisasi dalam politik adalah memisahkan agama dengan politik dengan alasan bahwa jika agama dicampur dengan politik (negara) maka agama akan digunakan untuk kepentingan kelompok elit negara atau "politisasi agama" 7 . Kaum sekuler beryakinan bahwa agama sebagai wilayah pribadi dan politik (negara) adalah wilayah publik, agama adalah hal yang suci sedangkan politik adalah hal yang kotor dan profan. ${ }^{8}$ Secara garis besar sekularisasi ditandai oleh pemisahan antara

${ }^{5}$ Penelitian Saiful Mujani dalam konteks di Indonesia menunjukkan bahwa Islam memiliki korelasi negatif terhadap partisipasi politik, tidak terbukti dan tidak ada satu pun unsur Islam yang menunjukkan korelasi negatif terhadap partisipasi politik tersebut. Bahkan sebaliknya, sebagian besar unsur Islam memiliki korelasi positif terhadap partisipasi politik. Baik partisipasi politik tersebut bersifat keagamaan maupun non-keagamaan. Saiful Mujani, Muslim Demokrat; Islam, Budaya Demokrasi, dan Partisipasi Politik di Indonesia Pasca-Orde Baru (Jakarta: Gramedia Pustaka Utama, 2007), 253 dan 319. Robert W Hefner, Civil Islam: Muslims and Democratization in Indonesia (New Jersey: Princenton University Press, 2011), 231.

${ }^{6}$ Syed Muhammad Naquib Al-Attas, Islam dan Sekularisme, (Kuala Lumpur : International Institute of Islamic Thought and Civilization (ISTAC) 2011), 18.

7 Yusuf Qardhawi berpandangan bahwa sekularisme adalah pemisahan agama dari kehidupan individu atau sosial. Tuhan dan hokum-hukumNya tidak boleh mengatur mereka seakan tuhan mereka adalah diri mereka sendiri, berbuat dan membuat hukum sesuai dengan seleranya, dan hal tersebut sangat bertentangan dengan syariat IslamYusuf Qardhawi, Sekuler Ekstrim. Penerjemah Nabhari Idris, cet. 1 (Jakarta: Pustaka al-Kautsar, 2000)

${ }^{8}$ Adian Husaini, Wajah Peradaban Barat, Dari Hegemoni Kristen ke Dominasi Sekuler-Liberal, 39.

TAJDID Vol. XVI, No. 2, Juni - Desember 2017 | 193 


\section{Said Abdullah Syahab}

pemerintahan dan ideologi-ideologi keagamaan serta struktur keagamaan. ' Kemudian terjadinya pengembangan (ekspansi) pemerintahan untuk melaksanakan peranan mengatur lapangan sosioekonomis yang dulu dilakukan oleh struktur-struktur keagamaan, transvaluasi budaya politik untuk menekankan tujuantujuan duniawi yang non-transenden dan cara-cara yang rasional serta pragmatis yang berupa nilai-nilai politik sekuler ${ }^{10}$.

Pada prinsipnya, sekularisme tidak memiliki akar di dalam Islam. Islam tidak pernah memberikan tempat bagi sekularisme, karena sebagai agama wahyu, Islam tidak mengenal dikhotomi secara tegar antara kehidupan dunia dan kehidupan akherat antara yang profan dan yang sakral, antara yang immanen dan yang transenden. Karena itu, doktrin Nasrani "render unto Caesar the things which are Caesar's; and unto God the things which are God's" tidak dikenal dalam agama Islam. ${ }^{11}$ Lahirnya konsep sekularime bermula dari zaman pencerahan pada abad ke-17 sampai 19, bersamaan dengan keruntuhan keyakinan keagamaan kristen oleh arus kebangkitan akal rasional, empirisme, serta kemajuan sains dan

\footnotetext{
9 "Sekularisme" adalah sebuah faham, maka "sekularisasi" adalah sebuah proses, yakni proses pemisahan antara urusan-urusan dunia dengan urusan agama Harvey Cox, The Secular City (New York: The Macmillan Company, 1966), h. 2

${ }_{10}$ Donald Eugene Smith, Agama dan Modernisasi Politik, Penerjemah Drs. Machnun Husen

(Jakarta: CV. Rajawali), h. 115-116 Harun Hadiwiyono, Sari Sejarah Filsafat Barat 2 (Yogyakarta: Kanisius, 1980), 56.

11 M. Amin Rais, "Kata Pengantar" dalam John J. Donohue dan John L. Esposito, Islam dan Pembaharuan, Penerjemah Machnun Husein (Jakarta: CV Rajawali, 1984), h. xvi. Pada pertengahan awal abad ke-19, filsuf-sosiolog Prancis, Auguste Comte, telah membayangkan kebangkitan sains dan kejatuhan agama dan meyakini, bersesuaian dengan logika sekular perkembangan filsafat dan sains Barat, bahwa masyarakat 'berevolusi' dan 'berkembang' dari tahap primitif ke modern. Kemudian dengan melihat dari aspek perkembangan metafisik terjadi pergeseran dari teologi kepada sains. Dilanjutkan pada abad yang sama, filsuf-penyair dan peramal Jerman, Friedrick Nietzsche, mengeluarkan pernyataan fenomenalnya bahwa Tuhan telah mati. Adian Husaini, Wajah Peradaban Barat, Dari Hegemoni Kristen ke Dominasi Sekuler-Liberal (Jakarta: Gema Insani Press, 2005), 3-50. Michael Baigent, Richard Leigh, Henry Lincoln, The Messianic Lagacy (New York: Dell Publishing, 1986), 36-42. 50. Syed Muhammad Naquib Al-Attas, Islam dan Sekularisme, 2.
}

194 | TAJDID Vol. XVI, No. 2, Juni - Desember 2017 
teknologi di Barat. ${ }^{12}$ Amin Rais menyakini bahwa setiap usaha untuk melancarkan sekularisasi di dunia Muslim tidak akan pernah bisa berhasil karena upaya sekularisme tidak memiliki akar dalam masyarakat Muslim.Dan masyarakat Islam akan menolak arus sekularisasi tersebut. ${ }^{13}$

Sebagai agama yang memberikan rahmat buat seluruh umat manusia, Islam memiliki prinsip-prinsip dasar dan tata nilai dalam mengelola organisasi atau pemerintahan. Dalam Al-Qur'an dan Assunnah terdapat beberapa prinsip pokok dan tata nilai yang berkaitan dengan kepemimpinan, kehidupan bermasyarakat, berorganisasi, dan bernegara (berpolitik). ${ }^{14}$ Prinsip-prinsip atau nilai-nilai tersebut diantaranya adalah prinsip tauhid, yang merupakan salah satu prinsip dasar dalam kepemimpinan Islam

12 Pertama, trauma sejarah yang sangat membekas atas nama agama oleh masyarakat barat pada abad pertengahan yang kemudian digambarkan oleh tokoh kontemporer Barat Scott Peck bahwa akumulasi dari kekecewaan masyarakat yang menjadi pembenaran untuk melakukan sekularisasi adalah sekali kata 'religion' disebutkan di dunia Barat, ini akan membuat orang berpikir tentang:...Inquisisi, tahyul, lemah semangat, paham dogmatis, munafik, benar sendiri, kekakuan, kekasaran, pembakaran buku, pembakaran dukun, laranganlarangan, ketakutan, taat aturan agama, pengakuan dosa dan kegilaan. Lebih lanjut ia menyatakan apakah semua ini yang Tuhan lakukan untuk manusia atau apa yang manusia lakukan untuk Tuhan. Kedua problema teks Bible yang akar masalahnya pernah di sebut oleh Profesor Bruce M.Metzger, seorang guru besar bahasa Perjanjian Baru di Princeton Theological Seminary menulis di pembukaan bukunya "A Textual Commentary on the Greek New Tentament" ada dua kondisi yang selalu dihadapi oleh penafsir Bible, yaitu (1) tidak adanya dokumen Bible yang original saat ini, dan (2) bahan-bahan yang ada pun sekarang ini bermacam-macam, berbeda satu dengan yang lain. Yang ketiga, problema Teologi Kristen misalnya tentang ketuhanan Yesus mencatat bahwa Kristen yang dikenal saat ini bukan berasal dari zaman Yesus, tetapi dari konsili Nicea, yang dicapai melalui pemungutan suara. Michael Baigent, Richard Leigh, Henry Lincoln, The Messianic Lagacy (New York: Dell Publishing, 1986), 36-42. Adian Husaini, Wajah Peradaban Barat, Dari Hegemoni Kristen ke Dominasi Sekuler-Liberal (Jakarta: Gema Insani Press, 2005), 3-51. Syed Muhammad Naquib Al-Attas, Islam dan Sekularisme, 2.

13 M. Amin Rais, "Kata Pengantar" dalam John J. Donohue dan John L. Esposito, Islam dan Pembaharuan, Penerjemah Machnun Husein Jakarta: CV Rajawali, 1984), h. xvi.

14 Muhammad Imarah, Mencari Format Peradaban Islam, (Jakarta: Raja Grafindo Persada, 2005), 85.

\section{TAJDID Vol. XVI, No. 2, Juni - Desember 2017| 195}




\section{Said Abdullah Syahab}

(pemerintahan Islam). Kemudian prinsip musyawarah (syuro), dalam pengertian mengajukan atau mengeluarkan pendapat, dalam menetapkan keputusan yang berkaitan dengan kehidupan bermasyarakat dan bernegara.

Dalam pandangan demokrasi, suara mayoritas menentukan keputusan baik yang terkait dengan kehidupan masyarakat maupun bernegara. Islam tidak menentang adanya mekanisme keputusan pendapat mayoritas selama tidak bertentangan dengan nilai-nilai syariah Islam selama keputusan mayoritas tersebut tidak menzalimi kelompok minoritas. Dalam Al-Quran dan As-Sunnah terdapat konsep musyawarah yang telah digunakan oleh umat Islam dalam membuat pedoman dalam sistem pemerintahan. Sistem pemerintahan merupakan hasil dari ijtihad masing-masing sistem pemerintahan yang disesuaikan dengan kondisi sosio-kultural yang merupakan hasil dari kontrak sosial dalam masyarakat Islam tersebut. ${ }^{15}$ Prinsip islam lainnya adalah prinsip keadilan (Al'adalah), dalam mengelola pemerintahan. Dan ajaran Islam telah menjadikan seorang pemimpin harus berlaku adil dalam mengelola negara untuk menciptakan masyarakat yang adil dan makmur. ${ }^{16}$

Dalam membedah hubungan Islam dan demokrasi tidak bisa lepas dari realitas pergulatan panggung politik, negara, kekuasaan dan pemerintahan. Islam mengedepankan kemaslahatan bagi umat Islam (konsep Al-maslahah) dalam mensikapi kondisi realitas suatu wilayah atau negara. Dengan dasar tersebut maka Islam bisa sejalan dengan demokrasi, tetapi dalam kondisi dan dalam hal tertentu dapat berseberangan dengan demokrasi. ${ }^{17}$ Terkait sikap terhadap demokrasi, baik yang menerima secara utuh maupun menolaknya, kecenderungan dengan mengambil sikap kristis untuk belajar dari nilai-nilai demokrasi dari Barat dengan segala

15 Ali Syari'ati, Islam Maz̧ab Pemikiran dan Aksi (Bandung: Mizan, 1995), 15. Diterjemahkan dari beberapa artikel yang pernah dimuat di Kayhan International edisi tahun 1990-1992, diedit oleh Afif Muhammad.

16 Al-Mawardi, Al-Abkam as-Sulthaniyah wa al-Wilayah ad-Diniyyah Vol. 5 (Lebanon: Dar Al-Fikr, 1994), 74.

17 Robert W Hefner, dalam Bukunya yang berjudul Civil Islam: Muslims and Democratization in Indonesia (New Jersey: Princenton University Press, 2011), 231.

196 | TAJDID Vol. XVI, No. 2, Juni - Desember 2017 
kekurangan dan kelebihannya. Yang bisa dikontekstualisasikan dengan budaya lokal pun bisa dipakai, sementara yang tidak bisa dikontekstualisasikan dengan budaya lokal sebaiknya ditepiskan. Dengan demikian jika demokrasi dikontekstualisasikan dengan tepat, demokrasi dapat relevan dengan konteks masyarakat Islam. ${ }^{18}$

Sejak berakhirnya Perang Dunia II, gelombang demokrasi telah meluas ke berbagai negara, tidak terkecuali negara-negara berpenduduk muslim. Demokrasi adalah sistem politik ${ }^{19}$ yang menjamin kedaulatan rakyat dengan terbentuknya pemerintahan dari rakyat, oleh rakyat dan untuk rakyat. ${ }^{20}$ Pemilihan umum secara periodik untuk melakukan kepemimpinan negara. Dimana mekanisme ini memungkinkan terwujudnya artikulasi kehendak politik rakyat. ${ }^{21}$ Arus perubahan yang mendorong demokratisasi pemerintahan lokal telah terjadi di berbagai negara dengan melaksanakan reformasi politik dan demokrasi yang cenderung pada desentralisasi dan pemberdayaan pemerintahan lokal. ${ }^{22}$ Walau di antara pemikir Islam masih memiliki perbedaan dalam hal ini,

18 Robert W Hefner, Remaking Muslim Politics: Pluralism, Contestation, Demoratization (New Jersey: Princenton University Press, 2004), 184.

19 Sistem biasanya diartikan sebagai komponen-komponen yang membentuk kesatuan yang utuh. Politik adalah sebuah konsep yang berhubungan dengan kekuasaan (power) atau secara institusional bermakna negara. Jadi, yang dimaksud sistem politik di sini adalah suatu konsepsi yang jalin-menjalin di dalamnya ketentuan tentang sumber kekuasaan-negara, siapa pelaksana kekuasaan tersebut, cara menentukan pemberian kewenangan melaksanakan kekuasaan, bentuk pertanggungjawaban kekuasaan dan kepada siapa pelaksana kekuasaan itu bertanggungjawab. Dengan demikian, ada empat variable dalam sistem politik, yakni kekuasaan, kepentingan, kebijakan, dan budaya politik. t Miriam Budiardjo, Dasar - dasar Ilmu Politik (Jakarta: Gramedia, 1986) 46-49. Ramlan Surbakti, Memahami Ilmu Politik (Jakarta: Grasindo, 1993), 281.

${ }^{20}$ Government of the people, by the people, and for the people. government of the people, by the people, and for the people..Gabor S. Borritt dan Bradley R. Hoch, The Lincoln Trail in Pennsylvania (Pennsylvania: Pennsylvania State University Press, 2001), 51.

21 Samuel P. Huntington, The Third Wave: Democratization in The Late Twentieth Century (London and Norman: University of Oklahoma Press, 1991), 127.

22 Brian Clive Smith, Understanding Third World Politics: Theories of Political Change and Development (Indiana USA: Indiana University Press, 2003), 231.

TAJDID vol. XVI, No. 2, Juni - Desember 2017| 197 


\section{Said Abdullah Syahab}

ada yang memandang demokrasi sebagai sistem yang kompatibel dengan Islam ${ }^{23}$ dan ada pula yang memandang inkompatibalitas Islam dengan demokrasi dengan menekankan pemilihan dilakukan secara bebas, akuntabilitas, transparansi, penegakan hukum dan perlindungan hak asasi manusia. ${ }^{24}$

Pada masa kontemporer dunia Islam saat ini, demokrasi telah menjadi sistem banya yang telah digunakan oleh umat Islam. Revolusi yang terjadi negara-negara di Timur-Tengah menunjukkan Negara-negara yang mayoritasnya umat Islam telah menyongsong demokrasi dan momen revolusi tersebut dalam rangka memperjuangkan lahirnya demokrasi. ${ }^{25}$ Lahirnya era demokrasi ini merupakan bagian dari perlawanan terhadap rezim diktator yang telah berkuasa di negara-ngara muslim di Timur Tengah yang menggunakan demokrasi sebagai katalisator untuk

\footnotetext{
${ }^{23}$ Mark Tessler, "Islam and Democracy in the Middle East: The Impact of Religious Orientations on Attitudes toward Democracy in Four Arab Countries," Comparative Politics, 34 (April 2002): 340. Lihat juga Fred Halliday, Islam and the Myth of Confrontation: Religion and Politic in the Middle East (London: I. B. Tauris, 1995), 116. John Esposito and John Voll, Islam and Democracy (Oxford: Oxford University Press, 1996). Mohamed Elhachmi Hamdi, "Islam and Democracy: The Limits of the Western Model," Journal of Democracy, 7 (April 1996): 81-85 dan Fatima Mernissi, Islam and Democracy: Fear of the Modern World (Reading: Addision-Walley, 1992).

${ }^{24}$ Ephraim Yuchman-Ya'ar and Yasmin Alkaray, "Political Attitudes in the Muslim World," Journal of Democracy, 21 (July 2010): 1. Samuel P. Huntington, The Clash of Civilization and the Remaking of World Order (New York: Simon and Schuster, 1996), 217. Azzam Tamimi, "Islam and Democracy from Tahtawi to Ghannouchi," Theory, Culture and Society 24 (Mach 2007): 39-58,. Y Choueiri, "The Political Discourse of Contemporary Islamist Movements," in Abdel Salem Sidahmed and Anoushiravam Ehteshami, eds., Islamic Fundamentalism (Boulder: Westview Press, 1996). Bernard Lewis dalam, The Shaping of the Modern Middle East (New York: Oxford University Press, 1994), 54-56.

${ }^{25}$ Dina Shehata, "The Fall of the Paraoh: How Hosni Mubarak's Reign Came to an End," in The New Arab Revolt: What Happend, What it Means, and What Comes Next (New York: Foreign Affairs, 2011), 146-148. Lihat juga, Bruce Feiler, Generation Freedom: the Middle East Uprisings and the Remaking of the Modern World (New York: Harper Parennial, 2011), 3-24, menyatakan bahwa Tahrir Square menjadi saksi sejarah tentang kembalinya kebebasan dan demokrasi ke Mesir. Tabrir Square dijadikan sebagai tempat shalat Jumat dan shalat lima waktu, tetapi juga pusat penggulingan rezim Hosni Mubarak. Para demonstran meneriakkan demokrasi dan kebebasan.
} 
mempertahankan kekuasaan dan mengutamakan kepentingan penguasa serta telah gagal dalam upaya menciptakan kesejahteraan dan keadilan sosial. ${ }^{26}$

Otoritarianisme politik di dunia Islam telah menjadikan Islam sering hanya menjadi subordinasi politik. ${ }^{27}$ Sistem mono-partai juga dapat mencegah tumbuhnya partai politik, sehingga tidak melahirkan persaingan yang demokratis melalui pemilu yang kompetitif, akuntabel dan transparan. $^{28}$ Kemiskinan dan keterbelakangan yang dirundung dunia Islam khususnya di Timur Tengah telah membangkitkan kesadaran umat Islam dari bahaya rezim otoriter. Ketidakadilan rezim-rezim otoriter mendorong kaum Islamis bergerak mengambil bagian dalam perebutan kekuasaan negara dengan membentuk patai politik dan ikut dalam proses demokrasi.Realiltas ini yang membuat para tokoh muslim menilai bahwa pandangan mengenai demokrasi dengan Islam tidak penting lagi untuk diperdebatkan dan mendorong gerakan Islam untuk ikut dalam sistem demokrasi karena menilai ini yang paling memungkinkan umat Islam untuk melepaskan dari kezaliman pemimpinnya dan kehancuran negara. Walau demokrasi di negaranegara Arab di Timur Tengah masih dianggap beberapa peneliti menyatakan bahwa negara-negara Muslim Non-Arab jauh lebih demokratis dibandingkan dengan negara-negara Arab. ${ }^{29}$

Menguatnya kesadaran umat Islam denga tumbuhnya gerkan Islam di negara-negara mayoritas muslim sejak jatuhnya Dinasti Ottoman di Turki pada tahun $1923 .{ }^{30}$ Gerakan tersebut menjadikan

${ }^{26}$ John Waterbury, "Democracy without Democrats?: the Potensial for \{Political Liberalization in the Middle East," in Democracy without Democrats?: The Renewal of Politics in the Muslim World (New York: I. B. Tauris, 2011), 25-23.

${ }^{27}$ Abdurraḥmān al-Kawākibī, Țabāi' al-Istibdād wa Mașāri' al-Isti'bād (Damaskus: Al-Awāil, 2003), 27. Menurut Rone Raz dalam "Interpretation of Kawākibīs Thought, 1950-1980s," Middle Eastern Studies, 32 (January, 1996): 179,

${ }^{28}$ Alfred Stepan and Graeme B. Robertson, "Arab, Not Muslim, Exceptionalism, Journal of Democracy, 15 (October 2004): 5

${ }^{29}$ Alfred Stepan and Graeme B. Robertson, "Arab, Not Muslim, Exceptionalism, Journal of Democracy, 15 (October 2004): 5.

${ }^{30}$ Ladan Boroumand and Roya Boroumand, "Terror, Islam, and Democracy," Journal of Democracy 13 (April, 2002): 4-5. Kebangkitan kesadaran nasional negara-negara Arab, The Awakening Arab Nation, dibelokkan tidak

TAJDID Vol. XVI, No. 2, Juni - Desember 2017 |199 


\section{Said Abdullah Syahab}

ideologi dan program yang bersumber langsung dari ajaran Islam dengan menjadikan al-Quran dan Sunnah sebagai landasannya. ${ }^{31}$ Dan jika diterima oleh rakyat secara demokratis, Gerakan Islam ini ingin mewujudkan pemerintahan Islam berdasarkan Syariat Islam. ${ }^{32}$ Yang menarik adalah para peneliti Barat sangat tidak menginginkan keterlibatan gerakan Islam modern dalam demokrasi di negara-negara timur tengah dan menganggapnya Gerakan Islam seperti Ikhwanul Muslimin di Mesir sebagai terorisme dan halangan serius bagi demokrasi sehingga demokrasi hanya menjadi

melawan imperialisme Barat; Inggris, Perancis, Jerman, dan Italia. Akan tetapi, berbalik menjadi menentang Kesultanan Turki Dengan dikembangkan gerakan sekularisasi. Di Turki, Kemal Pasha berhasil membubabarkan gerakan PanIslamisme yang merupakan gerakan anti-imperialism Barat dan mematahkan gerakan Islam. Kemudian menegakkan Turki sebagai negara Republik Sekuler Turki,1924 M. maka segenap kekuatan Kesultanan Turki dengan Islamnya, sebagai penghambat kemajuan Imperialis Barat, dapat dipatahkan oleh pemimpin turki dengan dukungan Barat. Nasionalisme Arab sebagai bentuk perlawanan terhadap penguasa kolonial Kesultanan Turki Usmani. Pada 1875, sekolompok orang Muslim berpendidikan Barat dan para intelektual Arab Kristen di Beirut menyatakan perlunya studi sejarah, sastra dan bahasa Arab untuk membangkitkan identitas Arab. Melalui publikasi dan cetakan mereka berupaya untuk mengangkat kekejaman pemerintahan Turki Usmani serta berusaha membangkitkan suatu "kesadaran Arab" sebagai satu keseluruhan. Setelah selama berabad-abad kemudian, Nasionalisme sekuler Arab sebelum perang dunia beranjak dari ungkapan Islam menuju ungkapan nasionalis di tengah perjuangan untuk meraih otonomi dari pemerintah pusat di Istambul Turki. Tuntutan otonomi ini kemudian berkembang menjadi tuntutan ke arah Arab merdeka. Dalam perkembangan selanjutnya memicu berbagai tuntutan dari sejumlah negara-negara Arab untuk memisahkan diri dari pemerintah Kesultanan Turki Usmani Ira M.Lapidus, Sejarah Sosial Umat Islam, bagian ketiga (Jakarta: Rajawali Press, 1988), 178. dhyaksa Dault, Islam dan Nasionalisme Reposisi Wacana Universal Dalam Konteks Nasional (Jakarta: Pustaka Al-Kautsar, 2005), 24. Ahmad Mansur Suryanegara, Api Sejarab-Mahakarya Perjuangan Ulama dan Santri dalam Menegakkan Negara Kesatuan Republik Indonesia Cetakan III (Bandung: Salamadani Pustaka Semesta, 2010), 336.

${ }^{31}$ Najib Ghadbian, Democratization and the Islamist Challenge in the Arab World (Boulder, CO and Oxford: Westview Press, 1997), 6.

${ }^{32}$ Salwa Ismail, "Being Muslim: Islam, Islamism and Identity Politics," Goverment and Opposition 39, no. 4 (2004): 66. Menurut Jon Armajani dalam, Modern Islamist Movements: History, Religion, and Politics (United Kingdom: WileyBlackwell, 2012), 1. 
milik negara Barat dan kaum sekuler serta menganggap ajaran Islam bertentangan dengan demokrasi. ${ }^{33}$

Kehawatiran keikutsertaan Gerakan Islam dalam demokrasi telah banyak dinyatakan oleh peneliti barat yang cenderung menganut islam phobia dan menuduh kelompok Islam yang menerima demokrasi hanya secara prosedural, tetapi di sisi lain mereka mempunyai intensi untuk membangun demokrasi dengan cita-rasa Islam. ${ }^{34}$ Khawatiran terhadap gerakan Islam bukan hanya oleh negara Barat, kaum sekuler juga merasakan sebagai ancaman atas kekuasaan Mesir yang selama ini dkuasai kalangan nasionalis sekuler.

\section{Ikhwanul Muslimin di Mesir}

Keikutsertaan Gerakan Islam dalam demokrasi di Mesir salah satu dilakukan oleh gerakan Ikhwanul Muslimin yang didirikan pada tahun 1928 oleh Hasan al-Banna (1906-1949). Gerakan ini lahir atas keprihatinan al-Banna melihat bentuk pengaruh modernisasi sekuler Barat pada nilai-nilai Islam serta kelemahan pemerintah yang kurang tanggap menghadapi kesenjangan sosioekonomi masyarakat Mesir. Tujuan dari gerakan ini adalah mengajak umat Islam untuk kembali kepada prinsip-prinsip Islam yang bersumber pada al-Qur`an dan Sunnah.

Gerakan Islam yang ingin mengembalikan Islam dalam kehidupan bermasyarakat dan bernegara pada umumnya akan mendapat sorotan sebagai terorisme (fundamentalis), hal tersebut juga ditujukan kepada kepada Ikhwanul Muslimin di Mesir, yang

33 Peneliti Barat berpandangan bahwa kalangan Islamis sejak tahun 1942 mempunyai agenda yang sejalan dengan Syariat Islam dan bertentangan dengan prinsip-prinsip demokrasi. Abdullāh Sāmī Ibrāhīm al-Dallāl, Al-Islämiyyün wa alDimuqrātiyyyah fì Mișr: 'Așfun wa Ramimun (Kairo: Maktabah Madbūlī, 2006), 319. Ladan Boroumand and Roya Boroumand, "Terror, Islam, and Democracy," 4.

${ }^{34}$ Masdar Hilmy, Islamism and Democracy in Indonesia: Piety and Pragmatism (Singapore: Institute of Southeast AKehsian Studies, 2010), 6.

${ }_{35}$ Manfred Halpern, The Politics of Social Change in the Middle East and North Africa (Princeton: University Press, 1963), h. 134-150.

TAJDID vol. XVI, No. 2, Juni - Desember 2017| 201 


\section{Said Abdullah Syahab}

didirikan oleh Hasan al-Banna pada tahun 1928. ${ }^{36}$ Ikhwanul Muslimin merupakan gerakan Islamis yang pertama kali muncul di dunia Islam dengan misi mempersatukan kembali kekuatan politik umat Islam di dunia. Oleh karena itu, mereka mengusung ideologi, "Pan-Islamisme"." Kebangkitan gerakan Islam ini merupakan perlawanan terhadap imprealisme Barat dan seiring runtuhnya Dinasti Ottoman di Turki pada tahun 1923. Gerakan Islam ini mengalami pasang surut dalam perjuangan politiknya, tantangan berat harus dihadapi gerakan Islam ini karena negara Barat menilai gerakan ini sebagai ancaman serius dan menggunakan pemimpin yang berkuasa di Mesir untuk menghambat bahkan menghancurkan gerakan Islam seperti yang dialami Ikhwanul Muslimin bahkan upaya ini berhasil dengan dibunuh pemimpin gerakan ini yakni Hasan Al- Banna.

Pasca wafatnya Hasan Al-Bannā pada tahun 1949 dianggap negara Barat sebagai kemenangan untuk memudarkan gerakan tersebut. Pasca revolusi 1954, Ikhwanul Muslimin dilarang oleh Gamal Abdul Naseer yang memilih komunisme sebagai ideologi negara. Sayyid QuTTb sebagai salah tokoh yang sangat berpengaruh di Ikhwanul Muslimin pun dieksekusi oleh rezim yang berkuasa pada tahun $1966 .{ }^{38} \mathrm{Namun}$ walau para tokoh terkemuka di gerakan Islam ini telah wafat, pemikiran dan ruh semangat perjuangan Ikhwanul Muslimin masih tetap hidup bahkan menjadi rujukan Umat Islam, tulisan sayyid qutb yang sampai saat ini menjadi kajian dan diskusi para pemuda Islam dan pemikir Islam kontemporer

${ }^{36}$ Olivier Roy, The Failure of Political Islam, translated by Carol Volk (Cambridge, MA: Harvard University Press, 1994), 35. Richard P. Mitchell, The Society of the Muslim Brothers, (London: Oxford University Press, 1969

${ }^{37}$ Pada mulanya, Pan-Islamisme diusung oleh Jamāl al-Dīn al-Afghānī (1838-1897), Muhammad Abduh (1849-1905) dan Muhammad Rashīd Rid a (1865-1935). Ideologinya berdiri di atas pemikiran perlunya perlawanan terhadap Barat dalam rangka meraih kemerdekaan dan solidaritas keislaman. Ketiga sosok reformis Muslim tersebut menjadikan ijtihad sebagai pintu masuk mencapai solidaritas umat Islam. Namun, pada tahun 1928, Hasan al-Bannā mentransformasikannya menjadi gerakan politik sebagai awal dari kebangkitan ideologi Pan-Islamisme dalam ranah politik.

${ }^{38}$ Nazih N. M. Ayyubi, "The Political Revival of Islam: The Case of Egypt," in An Anthology of Contemporary Middle Eastern History, edited by Syafiq Mughni (Canada: Canadian International Development Agency), 571-572. 
hingga saat ini. Di antara bukunya yang sangat terkenal yakni manifesto pergerakan yang kemudian dijadikan sebagai rujukan utama, yaitu Ma'älim fì al-Ţariq, tulisan dalam buku ini memantapkan al-Quran dan Sunnah sebagai ideologi pergerakan. Kesabaran dan kegigihan serta semangat dari penerus Ikhawanul Muslimin pada akhirnya berhasil membebaskan mereka dari kezaliman yang dlakukan pada pemerintahan sebelumnya. Pada tahun 70-an, Presiden Anwar Sadat memberikan kebebasan politik kepada Ikhwanul Muslimin dengan memperkenankan mereka membuka kembali kantor dan melaksanakan aktivitas. ${ }^{39}$ Ikhawanul Muslimin tetap komitmen ideologi dan strategi pergerakannya yang telah dilakukan oleh pendahulunya.

Ikhwanul Muslimin pun harus rela mengalami kembali "ujian perjuangan" di masa berkuasanya Hosni Mubarak sebagai Presiden pasca-tewasnya Anwar Sadat pada tahun 1981. Ikhwanul Muslimin diperlakukan lebih buruk daripada pendahulunya. Gerakan Islam ini diperlakukan secara represif dan diskrimatif. Pemimpin dan aktivis Ikhwanul Muslimin ditangkap, dipenjara, disiksa, bahkan dibunuh tanpa melalui proses hukum yang adil. Namun simpatik dan dukungan rakyat Mesir terhadap gerakan Islam ini semakin besar dalam perjalanan waktunya, hal ini dapat dlihat gerakan Islam ini dari perjalanan politik Ikhwanul Muslimin pada tahun 1984 dan puncaknya, pada pemilu 2005, mereka mendapatkan 88 kursi di parlemen. Fakta ini telah menyadarkan Hosni Mubarak, bahwa Ikhwanul Muslimin mempunyai basis politik yang riil di tengah-tengah masyarakat. Dalam kondisi politik yang represif pun, mereka masih mendapatkan perolehan suara yang cukup signifikan. ${ }^{40}$

Tidak hanya itu saja, pengaruh Ikhwanul Muslimin semakin meluas di berbagai dunia Islam, khususnya di negara-negara Timur-Tengah lainnya, seperti Suriah, Yaman, Libya, Libanon, AlJazair, Maroko, dan lain-lain. Mereka kerapkali membangun aliansi dengan Hamas, terutama dalam konteks perlawanan terhadap

${ }^{39}$ John L. Esposito and John O. Voll, Islam and Democracy (Oxford: Oxford University Press, 1996), 174-175.

${ }^{40}$ Jon Armanjani, Modern Islamist Movements: History, Religion, and Politics (United Kingdom: Wiley-Blackwell, 2012), 63-76.

TAJDID vol. XVI, No. 2, Juni - Desember 2017| 203 


\section{Said Abdullah Syahab}

Israel dan upaya meraih kemerdekaan Palestina. ${ }^{41}$ ersamaan dengan Revolusi yang melengserkan Hosni Mubarak Ikhwanul, Ikhawanul Muslimin. ${ }^{42}$ mendirikan partai politik pasca-revolusi yaitu Hizb alburriyyah wa al-'Adālah (Partai Kebebasan dan Keadilan) yang didukung oleh Dewan Agung Militer Mesir yang meminta Ikhwanul Muslimin juga terlibat dalam proses amandemen konstitusi. Dan atas dukungan rakyat mesir, Ikhwanul Muslimin pasca-revolusi mendapatkan suara yang signifikan dalam pemilu tersebut. $^{43}$

Pada prinsip Ikhwanul Muslimin mendukung konsep negara bangsa (nation-state) selama ini menjadi keinginan dan kehendak rakyat Mesir dengan tetap mengedepankan nilai-nilai Islam. ${ }^{44}$ Dan Ikhwanul Musliminpun mendapat dukungan dari kalangan Kristen Koptik seperti di Alexandria yang merupakan basis komunitas Kristen Koptik. Ikhwanul Muslimin juga memberikan hak wanita khususnya dalam politik praktis yang menunjukkan adanya kesetaraan jender dalam ranah politik. Sebagai kekuatan politik baru, Ikhwanul Muslimin mempunyai ideologi Islamis (al-'aqidab) dengan basis pengikut yang sangat militan dalam menegakkan ideologi tersebut slamis dan pendanaan yang cukup baik ${ }^{45}$

\section{Penutup}

Gerakan Pan Islamisme atau Revivalisme Islam yang muncul pada awal abad ke-20 di Timur Tengah, ternyata tumbuh menjadi kekuatan yang bersifat ganda, di satu pihak sebagai gerakan

${ }^{41}$ Anders Strindberg and Mats Wärn, Islamism (United Kingdom: Polity Press, 2011), 87-90. Barry Rubin, The Muslim Brotherhood: The Organization and Policies of Global Islamist Movement (New York: Palgrave Macmillan, 2010), 1-3.

42Shadi Hamid, "The Rise of the Islamists: How Islamists Will Change Politics, and Vice Versa," in The New Arab Revolt (New York: The Council of Foreign Relations, 2011), 360.

${ }^{43}$ Dalam pemilu yang digelar pada pemilu pertama pasca revolusi, Ikhwanul Muslimin mendulang suara mayoritas di parlemen, yaitu sekitar $40 \%$.

44 Vali Nasr, "The Rise of Muslim Democracy," Journal of Democracy, 16 (April, 2005): 13-26. M. Hakan Yavuz, Secularism and Muslim Democract in Turkey (Cambridge: Cambridge University Press, 2009).

45 Nalar politik ini dinyatakan oleh Muhammad 'Abid al-Jābirī dalam $A l$ 'Aql al-Siyāsì al-'Arabi: Mubaddidātubū wa Tajalliyātubū, Markaz (Beitut: Dirāsāt alWị̣dah al-'Arabiyyah, Cetakan VI, 2007). 
kebangkitan Islam untuk melawan keterbelakangan, kebodohan, kemiskinan sekaligus sebagai kebangkitan umat Islam yang sebelumnya meninggalkan sebagian ajaran Islam. $^{46}$ Dan Mesir dengan dipolopori oleh Gerakan Islam seperti Ikhwanul Muslimin telah melakukan perubahan mendasar dari sistem pemerintahan sekuler menuju pemerintahan yang menerapkan nilai-nilai Islam di pemerintahan negara tersebut bersamaan dengan era kesadaran umat Islam terhadap ajaran agama dalam kehidupan bermasyarakat dan bernegara. Upaya Ikhwanul Muslimin tidak mudah mengingat sekuler telah juga mengakar dalam pemerintahan sekuler dan kehadiran konsep Islam akan menganggu kepentingan Barat dan Israel.

\section{Daftar Pustaka}

Al-Attas, Syed Muhammad Naquib. Islam dan Sekularisme, Kuala Lumpur: International Institute of Islamic Thought and Civilization, (ISTAC) 2011.

Al-Dallāl, Abdullāh Sāmī Ibrāhīm. Al-Islämiyy ùn wa alDimuqräTizyah fi Mișr: 'AȘfun wa Ramimun, Kairo: Maktabah Madbūlī, 2006.

Al-Kawākibī, Abdurraḥmān. Țabāì al-Istibdād wa Mașāiri al-Istíbād, Damaskus: Al-Awāil, 2003.

Al-Mawardi, Al-Abkam as-Sulthaniyah wa al-Wilayah ad-Diniyyah Vol. 5, Lebanon: Dar Al-Fikr, 1994.

Armanjani, Jon. Modern Islamist Movements: History, Religion, and Politics, United Kingdom: Wiley-Blackwell, 2012.

Ayyubi, Nazih N. M. "The Political Revival of Islam: The Case of Egypt," in An Anthology of Contemporary Middle Eastern History,, Canada: Canadian International Development Agency.

Baigent, Michael. Richard Leigh, Henry Lincoln, The Messianic Lagacy, New York: Dell Publishing, 1986.

${ }^{46}$ Lihat Stoddard, The New World,48-49. Asghar Ali Engineer, Asal-Usul dan Perkembangan Islam, Analisis pertumbuban Sosio-Ekonomi (ter.) (Yogyakarta: Insist, 1999), 240.

TAJDID vol. XVI, No. 2, Juni - Desember 2017 | 205 


\section{Said Abdullah Syahab}

Boroumand, Ladan. and Roya Boroumand, "Terror, Islam, and Democracy," Journal of Democracy 13 (April, 2002)

Borritt, Gabor S. dan Bradley R. Hoch, The Lincoln Trail in Pennsylvania, Pennsylvania: Pennsylvania State University Press, 2001.

Budiardjo, Miriam. Dasar - dasar Ilmu Politik, Jakarta: Gramedia, 1986.

Cox, Harvey. The Secular City, New York: The Macmillan Company, 1966.

Dault, Adhyaksa. Islam dan Nasionalisme Reposisi Wacana Universal Dalam Konteks Nasional, Jakarta: Pustaka Al-Kautsar, 2005.

Engineer, Asghar Ali. Asal-Usul dan Perkembangan Islam, Analisis pertumbuhan Sosio-Ekonomi (ter.), Yogyakarta: Insist, 1999.

Esposito, John L. dan John Obert Vol.l, Islam and Democracy, New York: Oxford University Press, 1996.

-----, and John O. Voll, Islam and Democracy, Oxford: Oxford University Press, 1996.

-----, Islam dan Pembaharuan, Penerjemah Machnun Husein, Jakarta: CV Rajawali, 1984.

Ghadbian, Najib. Democratization and the Islamist Challenge in the Arab World, Boulder, CO and Oxford: Westview Press, 1997.

Halpern, Manfred. The Politics of Social Change in the Middle East and North Africa , Princeton: University Press, 1963.

Hamdi, Mohamed Elhachmi. "Islam and Democracy: The Limits of the Western Model," Journal of Democracy, 7 (April 1996).

Hamid, Shadi. "The Rise of the Islamists: How Islamists Will Change Politics, and Vice Versa," in The New Arab Revolt, New York: The Council of Foreign Relations, 2011.

Harun, Musa. al Hukmi fi Islam, Mesir: Dar al- Kitab al-Arabi al Ghazirah, 1963.

Hefner, Robert W. Remaking Muslim Politics: Pluralism, Contestation, Demoratization, New Jersey: Princenton University Press, 2004.

206 | TAJDID Vol. XVI, No. 2, Juni - Desember 2017 
Hilmy, Masdar. Islamism and Democracy in Indonesia: Piety and Pragmatism, Singapore: Institute of Southeast AKehsian Studies, 2010.

Huntington, Samuel P. The Clash of Civilization and the Remaking of World Order, New York: Simon and Schuster, 1996.

Husaini, Adian. Wajah Peradaban Barat, Dari Hegemoni Kristen ke Dominasi Sekuler-Liberal, Jakarta: Gema Insani Press, 2005.

Imarah, Muhammad. Mencari Format Peradaban Islam, Jakarta: Raja Grafindo Persada, 2005.

Ismail, Salwa. "Being Muslim: Islam, Islamism and Identity Politics," Goverment and Opposition 39, no. 4 (2004).

Lapidus, Ira M. Sejarah Sosial Umat Islam, bagian ketiga, Jakarta: Rajawali Press, 1988.

Lewis, Bernard. dalam The Shaping of the Modern Middle East, New York: Oxford University Press, 1994.

McLeod, Hugh. (ed), The Decline of Christendom in Western Europe,1750-2000, Cambridge: Cambridge University Press, 2005.

Mernissi, Fatima. Islam and Democracy: Fear of the Modern World (Reading: Addision-Walley, 1992).

Mitchell, Richard P. The Society of the Muslim Brothers, London: Oxford University Press, 1969.

Mujani, Saiful. Muslim Demokrat; Islam, Budaya Demokrasi, dan Partisipasi Politik di Indonesia Pasca-Orde Baru, Jakarta: Gramedia Pustaka Utama, 2007.

Natsir, Mohammad. Agama dan Negara dalam Perspektif Islam, Jakarta: Media Dakwah 2001.

Qardhawi, Yusuf. Sekuler Ekstrim. Jakarta: Pustaka al-Kautsar, 2000.

Rais, M. Amin. "Kata Pengantar" dalam John J. Donohue dan John L. Esposito, Islam dan Pembaharuan, Jakarta: CV Rajawali, 1984.

TAJDID vol. XVI, No. 2, Juni - Desember 2017| 207 


\section{Said Abdullah Syahab}

Roy, Olivier. The Failure of Political Islam, translated by Carol Volk, Cambridge, MA: Harvard University Press, 1994.

Shehata, Dina. "The Fall of the Paraoh: How Hosni Mubarak's Reign Came to an End," in The New Arab Revolt: What Happend, What it Means, and What Comes Next, New York: Foreign Affairs, 2011.

Smith, Brian Clive. Understanding Third World Politics: Theories of Political Change and Development, Indiana USA: Indiana University Press, 2003.

Smith, Donald Eugene. Agama dan Modernisasi Politik, Penerjemah Drs. Machnun Husen, Jakarta: CV. Rajawali.

Stepan, Alfred and Graeme B. Robertson, "Arab, Not Muslim,

Exceptionalism, Journal of Democracy, 15 (October 2004).

Surbakti, Ramlan. Memahami Ilmu Politik, Jakarta: Grasindo, 1993.

Suryanegara, Ahmad Mansur. Api Sejarah-Mabakarya Perjuangan

Ulama dan Santri dalam Menegakkan Negara Kesatuan Republik. Indonesia, Cetakan III, Bandung: Salamadani Pustaka Semesta, 2010.

Syari'ati, Ali. Islam Mą̧̧ab Pemikiran dan Aksi, Bandung: Mizan, 1995.

Tamimi, Azzam. "Islam and Democracy from Tahtawi to Ghannouchi," Theory, Culture and Society 24 (Mach 2007).

Thaba, Abdul Aziz. Islam dan Negara Dalam Politik Orde Baru Jakarta: Gema Insani Press, 1996.

Wärn, Strindberg Anders and Mats. Islamism, United Kingdom: Polity Press, 2011.

Waterbury, John. "Democracy without Democrats?: the Potensial for \{Political Liberalization in the Middle East," in Democracy without Democrats?: The Renewal of Politics in the Muslim World (New York: I. B. Tauris, 2011).

Yavuz, M. Hakan. Secularism and Muslim Democract in Turkey, Cambridge: Cambridge University Press, 2009.

208 | TAJDID Vol. XVI, No. 2, Juni - Desember 2017 